\title{
NEW POLICIES, MEASURES AND RESPONSIBILITIES OF POLLUTING INDUSTRIES: A CASE STUDY OF THE EGYPTIAN INDUSTRIES
}

\author{
Eid El-Ragehy and Doaa Salman
}

\begin{abstract}
The paper provides a new approach to estimating the damage resulting from industrial wastewater. The measurement method proposed can be applied for all industries to determine the damage resulting from wastewater and to compare it with the environmental load of each pollutant. These measures help identify the environmental responsibility of a particular firm for a specific period and a level of pollution. Furthermore, they are to determine clearly the main industries that are accountable for the highest environmental damage according to the water pollutant loads. During March 2019, the proposed approach was tested on Abu Qir industries that are located in Egypt. Results urge for applying the proposed measures to wastewater pollutions, as well as for updating the current legislation to stimulate a management system's efficiency. Results showed that phenol accounts for the highest percentage in paper production, followed by OILY pollutant in fertilizer production, $C O D$ and $B O D$ in paper production and TSS in fertilizer manufacturing. Determining accurately the environmental responsibility for damages accelerates the spread of the clean industries.
\end{abstract}

Keywords: waste water, environment responsibility, environmental damages

JEL Classification: Q53, M14, D81

\section{Authors:}

Eid El - Ragehy

Egyptian Ministry of Environment, Cairo, Egypt

E-mail: eid_eeaa@yahoo.com

https://orcid.org/0000-0001-5050-6104

Doaa Salman

October University for Modern Sciences and Arts, Cairo, Egypt

E-mail:dsalman@msa.eun.eg

https://orcid.org/0000-0001-8276-0959

Citation: El-Ragehy, E. \& Salman, D. (2020). New Policies, Measures and Responsibilities of Polluting Industries: A Case Study of the Egyptian Industries. Virtual Economics, 3(2), 77-94. https://doi.org/10.34021/ve.2020.03.02(5)

Received: February 16, 2020. Revised: March 26, 2020. Accepted: April 15, 2020.

(C) Author(s) 2020. Licensed under the Creative Commons License - Attribution 4.0 International (CC BY 4.0) 


\section{Introduction}

Industrial activities that pollute the environment vary, and it is important to recognize the location of these sources and estimate the amount and quality of pollutants resulting from them to determine whether they comply with legal limitations or not. By means of this data, there can be defined the enterprise's responsibility for environmental pollution in general, knowing all enterprises within a specific geographical area or that of the industrial sector to which they belong (petroleum - petrochemicals - yarn and weaving - dyeing - food). Environmental pollution includes the ecosystem pollution (water - air - soil) with various sources of pollution (agricultural - industrial - transport). Environmental institutions are concerned with preventing or reducing pollution sources with many plans and investments not only to protect the environment from pollution but also to reach natural resources integrated and ideal management.

Determining responsibility for pollution is very important in environmental decision-making as it prioritizes inspection and monitoring activity, as well as environmental financing and investment, in addition to determining the extent of the impact on the environment and public health. Inspection and review of the environment and monitoring, regardless of determining responsibility, seriousness, and importance, fail to achieve environmental objectives, which depend mainly on preventing and reducing pollution loads and managing natural resources.

Defining the pollution loads of a facility is an important indicator in determining the legal and technical path that must be followed, as well as in estimating the value of environmental compensation and the value of environmental degradation and estimating the cost of treatment in the long run, especially, since most environmental institutions depend only on the amount of water produced by the industrial facility only, not paying attention to the quality of that water and the extent of its pollution. Determining environmental loads in a country contributes to defining the importance of expanding industrial activities - in this sector or region - so that it does not reach the unsafe level of pollution that is difficult to treat and which may turn into dangerous pollution; as well as the importance of that industry to the national income, the number of employees, and various economic, social, and, sometimes, political factors.

This paper focuses on the wastewater that results from various industrial activities. As its quality varies according to the industry, as well as there are different amounts and methods of treatment, we will assume there is a certain amount in a certain watercourse range which must meet legal limits and standards. Then, it is possible through the proposed model to define the environmental responsibility for each of these industries and, thus, contribute to the quality of an environmental decision. In the following section we will focus on the methodology adopted and the sample applied for testing and the measure proposed. Finally, the recommendation is provided. Numerous Egyptian industries require new evaluation of the wastewater quality and a new shift to the use of more efficient and cleaner technologies, which make businesses consume the least amount of energy and resources and produce the 
minimum amount of gases and pollutants, as well as use certain criteria that limit the flow of waste and make it recyclable. These technological transformations or developments are called shifting to environmental efficiency. In light of this growing necessity, institutions must adopt effective systems to improve the effectiveness and efficiency of their environmental management systems. Then, environmental responsibility is an effective tool through which these measures can be undertaken. Although the notion of sustainable development is related to the macroeconomics analysis, environmental responsibility has a direct relationship to the micro economy. There is an integrative relationship between the two concepts, and this will be the focus of our research that attempts to answer the following basic question: What is the actual state of affairs regarding environmental responsibility of the industrial companies in Egypt? This question entail very important subquestions: In what way is environmental responsibility implemented by the organization and what is its role in supporting environmental management systems? To answer these questions, the research paper builds on the following three pillars:

- environmental responsibility;

- environmental problems and the nature of economic practices;

- the environmental strategy of the industrial company.

\section{The Literature Review}

Researchers have become interested in studying environmental responsibility of late. Most Western and Arab studies of this topic focus on the relationship between environmental variables and industrial activities. Among the most important of these studies are that by Scovill (1995), who examines the problems of assessing environmental liabilities, in addition to the accounting disclosure of some companies' environmental performance costs. Linowes (1972) shows information about the impact of the unit's activities on the society, with the applied model related to one of the costing areas that affect workers, environment and production. Besides, Estes (1974) emphasises the costs aspect resulting from the negative externality. This researcher focuses on the concepts of trading as related to the society wellbeing and the harm that a unit causes to the society.

The industrial enterprise's environmental responsibility aims mainly at raising awareness and preventing external impacts (externalities) of production that harm the natural wealth, which is formed of institutional measures preventing or limiting certain activities, methods, or products that pose a threat to the balance of the natural environment. Several theoretical approaches deal with the issue of the institution's environmental responsibility. A prominent researcher, Pigou (2013) believes that the institution's environmental responsibility stands out in its economic form from fees, royalties and subsidies that governments impose on institutions since the collection (fees) are almost like levies (royalties) and subsidies (which are funds provided to an industrial enterprise to encourage it to adopt "clean practices"). He also considers that royalties are imposed in the field of waste collection and treatment, while fees are used to fight pollution, and they can be imposed directly on waste (the most stimulating procedure), or imposed on products derived from the use of polluting production methods, and the use of subsidies. Pollution rights aim at distributing pollution resistance 
efforts among different actors while allowing public authorities to maintain the maximum total of pollutant emissions, as it is divided into a fixed number of individual negotiable emissions rights, and the public authority works on these rights by selling them at a fixed price or selling them by auction or by distributing them to the concerned institutions according to their production. Thus, they are allocated to every other company cleaner than those that have not yet implemented their rights to pollution, then, and in a certain area, the high degree of pollution by an institution can be compensated by a decrease in the degree of pollution by another institution by trading pollution licenses.

Qian et al. (2019), consider the importance of the type of the embodied emissions which is an appropriate approach to determining the environmental responsibility. It can be the production-based approach that places full responsibility on producers who benefit from the production of goods (e.g., the Kyoto protocol). While the consumption-based approach lays full responsibility on the final consumers who benefit from the consumption of goods. The third approach can be based on the earners of income from the production of goods (Liang et al., 2017; Marques et al., 2012).

The role of the public authority is to determine a comprehensive collective standard (maximum emission of pollutants) that must be met, but the burden is distributed among the various parties concerned through the market in which pollution rights are traded. The rules for the primary distribution of pollution rights are the prerogative of the public authority, and in this framework, the value provided for obtaining "pollution permits" aims to modify the environmental behaviour of an industrial enterprise not only by punishing the polluting enterprise, but also giving preference to those institutions that incorporate environmental considerations into their production and marketing policies, and, as a result, competition rules are changed in favour of enterprises that respect the environment and that get a preferential advantage over polluting enterprises.

\section{The Methods}

This paper is informed by the basic laboratory measurements that can be made for all industries, as well as by knowing the amount of water resulting from them accurately, and then an environmental load of each pollutant can be determined separately for all industries. But what applies to a single indicator can be generalized to all laboratory indicators, including the environmental responsibility of each facility in the same industrial sector. To define the environmental responsibility, it can be assumed that many scenarios may occur in the event of commitment of one or some of these facilities (at the same time or in succession) and, thus, a future scenario is produced for a specific period for the level of pollution in this region or this sector.

By means of the proposed model, it is possible to determine the environmental efficiency of these facilities, which do not exceed the legal limits, and to learn how close they are to these limits. We assume that there are many industrial enterprises (both violating and conforming to the legal limits) and we assume that the legal limits for a laboratory index are $10 \mathrm{mg} /$ litre 
and the amount of exchange is different for each facility as well as different concentrations, and the environmental load for this indicator is defined by the following:

First: determining an environmental load of this laboratory indicator through knowing the concentration as well as the amount of water that is spent annually, taking into account the number of working days, the number of shift hours and the maintenance periods.

$$
L=V \times C
$$

where $C$ is the concentration of the laboratory index;

$V$ is the amount of water annually;

$L$ is the actual environmental load for this indicator.

Second: knowing the maximum environmental load for this laboratory indicator by knowing the maximum law and the amount of water that is spent annually, taking into account the number of working days, the number of shift hours and the maintenance periods.

$$
L_{\text {law }}=V \times C_{\text {law }}
$$

where $C_{\text {law }}$ is the legal maximum for the laboratory indicator;

$V$ is the amount of water annually;

$L_{\text {law }}$ is the legal maximum environmental load for this indicator.

An example of this is as follows: assuming the presence of two facilities and analysing water samples in one of the indicators (the legal maximum is $10 \mathrm{mg} / \mathrm{m3}$ ), it was found that one of them did not exceed the limits $(7 \mathrm{mg} / \mathrm{m3})$ and the amount of the resulting water is 12000 m3 / year and the other facility exceeded the permissible limits (12 Mg / m3) and the amount of the resulting water is $5000 \mathrm{~m} 3$ / year. In conventional models, the environmental load for each of them is calculated as follows:

The actual environmental load of the first facility is:

$$
L=V \times C=12000 \times 7=84000 \mathrm{mg} 3 \mathrm{~m} / \text { year }
$$

The actual environmental load of the second facility is:

$$
L=V \times C=5000 \times 12=60000 m g 3 m / \text { year }
$$


By comparing the environmental load of the first facility (within the legal limits) with the environmental load of the second facility (violating the legal limits), we find out that the violating facility has an environmental load that is less than the corresponding facility due to ignoring the legal environmental load for each of them, which can be calculated as follows:

Legal environmental load of the first facility is:

$$
L_{\text {law }}=1200 \times 10=120000 \frac{m g}{m^{3}} \text { per year }
$$

Legal environmental load for the second facility is:

$$
L_{\text {law }}=5000 \times 10=40000 \frac{m g}{m^{3}} \text { per year }
$$

Therefore we have proposed a new model for determining the environmental responsibility of industrial enterprises by knowing the concentration of actual laboratory indicators and the amount of water discharged annually as well as their relationship to the permitted legal environmental load, and applying this model to the previous example shows the following:

$$
S=L_{l a w} \times L
$$

where $S$ is the actual environmental difference according to the legal limits;

$L$ is the actual environmental load for this indicator;

$L_{l a w}$ is the legal maximum environmental load for this indicator.

From the above, the environmental responsibility can be determined for each indicator separately, and the relative environmental responsibility of the establishment can be defined as follows. The indicators are evaluated according to a set of criteria such as cost of treatment. Thus, laboratory indicators can be divided into five groups and set a numerical value for them as in the following table.

Table 1. Groups of Indicators, Parameters and their Value

\begin{tabular}{lll}
\hline Groups & Parameters & Value \\
\hline Physical indicators & Ph, Electrical conductivity, Temp, --- & 1 \\
\hline Salt indicators & TDS, TSS, --- & 2 \\
\hline Heavy metal indicators & $\mathrm{Cd}, \mathrm{Ni}, \mathrm{Cu}, \mathrm{Cr},----$ & 5 \\
\hline Vital indicators & $\mathrm{DO}, \mathrm{COD}, \mathrm{BOD}---$ & 4 \\
\hline CATIONS & $\mathrm{Ca}, \mathrm{Mg}, \mathrm{Na}, \mathrm{K},---$ & 3 \\
\hline ANOIOS & So4, Hco3, No3, NH4, --- & 3 \\
\hline Industrial indicators & OILY \& GRAS, Phenol, Pesticides, -- & 2 \\
\hline Biological indicators & Probability count for alkaline & 3 \\
\hline
\end{tabular}

Source: prepared by the authors. 
We define the relative weight of each indicator separately, according to the previous evaluation table. The indicators that have been measured in practice already have a total relative weight of $1=$ for example. When selecting the following indicators $(C O D, B O D=4)$, (TSS, TDS $=2),(\mathrm{Cd}, \mathrm{Ni} 5=)$ and so on, the relative weight of these indicators can be calculated as follows:

Table 2. Waste Indicators Shown, their Value, and Weight

\begin{tabular}{llllllll}
\hline Indicator & COD & BOD & TSS & TDS & Cd & Ni & Total \\
\hline Value & 4 & 4 & 2 & 2 & 5 & 5 & 22 \\
\hline Weight & 0.1818 & 0.1818 & 0.0909 & 0.0909 & 0.2272 & 0.2272 & 1 \\
\hline
\end{tabular}

Source: prepared by the authors.

In the case of the initial establishment (conforming to the legal limits):

$$
S=120000-84000=36000 \frac{m g}{m^{3}} \text { annually }
$$

That is, this facility is in compliance with the legal limitations and prevents itself from spending $36,000 \mathrm{mg} / \mathrm{m3}$ annually even though the law allows it to do so, which means it is an environmentally efficient facility that can define this efficiency as follows:

$$
P=\frac{S}{L_{\text {law }}} \times 100
$$

where $P$ is the environmental efficiency of a facility in one laboratory index.

$$
P=\frac{36000}{12000} \times 100=30 \%
$$

In the same way, it is possible to learn the extent of environmental efficiency of the conforming facilities by knowing many of its environmental indicators, and therefore it can be defined how close it is to the legal limits on all indicators.

Table 3. The Pollution Indicator and Wastewater 10,000 m3 Annually

\begin{tabular}{lccccc}
\hline Indicator (mg / m3) & COD & BOD & TSS & PHENOL & NH4 \\
\hline The legal limits * & 10 & 8 & 30 & 5 & 4 \\
\hline Actual concentrations & 8 & 5 & 12 & 4 & 3 \\
\hline $\begin{array}{l}\text { Llaw -the maximum legal maximum } \\
\text { for the Llaw laboratory index }\end{array}$ & 100,000 & 80,000 & 30,000 & 50,000 & 40,000 \\
\hline $\begin{array}{l}\text { The actual load of the laboratory } \\
\text { index L }\end{array}$ & 80000 & 50000 & 12,000 & 40000 & 30000 \\
\hline Environmental difference - S & 20000 & 30000 & 18,000 & 10000 & 10000 \\
\hline Environmental efficiency-P & $20 \%$ & $37.5 \%$ & $60 \%$ & $20 \%$ & $25 \%$ \\
\hline
\end{tabular}

Source: prepared by the authors. 
This facility discharges $80,000 \mathrm{mg} / \mathrm{m}^{3}$ annually of COD and its environmental efficiency is $20 \%$, meaning that it prevents itself from spending $20,000 \mathrm{mg} / \mathrm{m} 3$ annually, and also disburses $50,000 \mathrm{mg} / \mathrm{m} 3$ annually from BOD and its environmental efficiency is $37.5 \%$ That is, it prevents itself from spending $30,000 \mathrm{mg} / \mathrm{m} 3$ annually, and it also spends 120,000 $\mathrm{mg} / \mathrm{m} 3$ annually from TSS and its environmental efficiency makes $60 \%$, meaning that it prevents itself from spending $180,000 \mathrm{mg} / \mathrm{m} 3$ annually; it also disburses $40,000 \mathrm{mg} / \mathrm{m} 3$ annually of PHENOL and its environmental efficiency is $20 \%$, that is, it prevents itself from dispensing $10,000 \mathrm{mg} / \mathrm{m} 3$ annually; it also discharges $30,000 \mathrm{mg} / \mathrm{m} 3$ annually of $\mathrm{NH} 4$ and its environmental efficiency is $25 \%$. It does not prevent itself from dispensing $10,000 \mathrm{mg} / \mathrm{m} 3$ annually. Through this environmental profile, it is possible to assess the environmental status of this facility and determine the environmental decision thereon (the number of inspections, audits, and environmental monitoring), see Table 4 and Table 5.

Table 4. Pollutant Types, their Value and Weighted Average According to the Organization's Environmental Efficiency

\begin{tabular}{lcccccc}
\hline Indicator (mg / m3) & COD & BOD & TSS & PHENOL & NH4 & Total \\
\hline Value & 4 & 4 & 2 & 2 & 3 & 15 \\
\hline Weighted average & 0.2666 & 0.2666 & 0.133 & 0.133 & 0.2 & 1 \\
\hline Environmental efficiency & $20 \%$ & $37.5 \%$ & $60 \%$ & $20 \%$ & $25 \%$ & \\
\hline Weighted average & 0.266 & 0.266 & 0.133 & 0.133 & 0.2 & \\
\hline $\begin{array}{l}\text { Organization } \\
\text { environmental efficiency }\end{array}$ & 5.32 & 9.975 & 7.98 & 2.66 & 5 & 30.95 \\
\hline
\end{tabular}

Source: prepared by the authors.

The government sets environmental efficiency at - P - equal $30.95 \%$ for an organization. In the case of the second enterprise (breaching the legal limits):

$\mathrm{S}=40,000-60,000=(-) 20,000 \mathrm{mg} / \mathrm{m} 3$ per year, the negative sign here indicates that the legal limit is exceeded, meaning that this facility does not conform to the legal limits and it discharges an additional load from this laboratory indicator with a quantity of $20,000 \mathrm{mg} / \mathrm{m} 3$ annually, even though the law does not allow it to do so. This means that it is a facility with negative environmental efficiency (it does not have environmental efficiency) and that this efficiency can be determined as follows:

$$
P=\frac{S}{L_{\text {law } \%}}
$$

where $P$ is the environmental efficiency of a facility in one laboratory index. 


$$
P=\frac{20000}{40000 \%}=(-) 50 \%
$$

In the same way, it is possible to learn the extent of the negative environmental efficiency of non-conforming enterprises by knowing many of its environmental indicators, and therefore it can be determined how close it is to the legal limits on all indicators.

Table 5. Assuming that a Facility has an Annual Output of 10,000 m3/year

\begin{tabular}{|c|c|c|c|c|c|}
\hline Indicator (mg / m3) & COD & BOD & TSS & PHENOL & $\mathrm{NH} 4$ \\
\hline The legal limits* & 10 & 8 & 30 & 5 & 4 \\
\hline Actual concentrations & 12 & 9 & 32 & 6 & 5 \\
\hline $\begin{array}{l}\mathrm{L}_{\text {law }} \text {-the maximum legal } \\
\text { maximum for the } \mathrm{L}_{\text {law }} \\
\text { laboratory index }\end{array}$ & 100,000 & 80,000 & 30,000 & 50,000 & 40,000 \\
\hline $\begin{array}{l}\text { The actual load of the } \\
\text { laboratory index } L\end{array}$ & 120,000 & 90,000 & 320,000 & 60,000 & 50,000 \\
\hline Environmental difference $-\mathrm{S}$ & (-) 20000 & (-) 01000 & $(-) 20000$ & $(-) 01000$ & $(-) 1000$ \\
\hline Environmental efficiency $-\mathrm{P}$ & (-) $20 \%$ & $(-) 12.5 \%$ & $(-) 6.66 \%$ & (-) $20 \%$ & $(-) 25 \%$ \\
\hline
\end{tabular}

Source: prepared by the authors.

In this case, this facility discharges $120,000 \mathrm{mg} / \mathrm{m} 3$ annually of COD and its environmental efficiency accounts for (-) $20 \%$, meaning that it discharges $20,000 \mathrm{mg} / \mathrm{m} 3$ annually overload, and also outputs $90,000 \mathrm{mg} / \mathrm{m} 3$ annually from BOD and its environmental efficiency makes ($12.5 \%$, meaning that it spends $10,000 \mathrm{mg} / \mathrm{m} 3$ annually of overload, and it also spends $320,000 \mathrm{mg} / \mathrm{m} 3$ annually of TSS and its environmental efficiency makes (-) $6.66 \%$, meaning that it spends $20000 \mathrm{mg} / \mathrm{m} 3$ per year (overload); the facility discharges $60,000 \mathrm{mg} / \mathrm{m} 3$ per year of PHENOL and its environmental efficiency makes (-) $20 \%$, that is, it discharges 10,000 $\mathrm{mg} / \mathrm{m} 3$ per year (overload); it also outputs $50,000 \mathrm{mg} / \mathrm{m} 3$ per year of $\mathrm{NH} 4$ and its efficiency is (-)25\% i.e. $10,000 \mathrm{mg} / \mathrm{m} 3$ per year of overload.

Through this environmental profile, it is possible to assess the environmental status of this facility and determine the environmental decision regarding it (the number of inspections, audits, and environmental monitoring), as well as the value of the environmental investment, compensation, and the value of environmental degradation. In the case of more than one facility, the amount of overload for each indicator can be estimated.

For establishments in a specific geographical area: 
We assume that there are 20 industrial facilities (10 violators +10 conforming to law) and the legal limits for a laboratory index are $10 \mathrm{mg} /$ litre and the amount of exchange is different as well as there are different concentrations, the environmental efficiency of the corresponding facilities can be neutralized as well as through the previous steps. The environmental responsibility of enterprises that breach the legal limits within the same geographical area can be determined by knowing the environmental position of an indicator and estimating the quantities of overload for each of them, then calculating the total overload and the responsibility of each facility. $R$ is the relative environmental responsibility of this indicator for the rest of the enterprises can be calculated as follows: Total overload $=$ Total overloads Ss; Rp Relative environmental responsibility for this indicator $=\mathrm{S} / \mathrm{Ss} \%$.

Table 6. Proposed Scenarios for Relative Environmental Responsibility of a Sample of Industries.

\begin{tabular}{|c|c|c|c|c|c|c|c|c|c|c|c|c|}
\hline & $Q$ & $\mathrm{~N}$ & $M$ & $\mathrm{~K}$ & $\mathrm{G}$ & 1 & $\mathrm{~F}$ & $\bar{E}$ & $\mathrm{D}$ & $\mathrm{C}$ & $B$ & $A$ \\
\hline Legal limits m3 & 10 & 10 & 10 & 10 & 10 & 10 & 10 & 10 & 10 & 10 & 10 & 10 \\
\hline $\begin{array}{l}\text { Actual } \\
\text { concentration } \\
\text { m3 }\end{array}$ & 22 & 20 & 20 & 19 & 18 & 17 & 16 & 15 & 14 & 13 & 12 & 11 \\
\hline & 100 & 200 & 300 & 100 & 500 & 200 & 400 & 300 & 400 & 300 & 200 & 500 \\
\hline $\begin{array}{l}\text { The total } \\
\text { amount of non- } \\
\text { conforming } \\
\text { wastewater is } \\
\text { m3 / annually }\end{array}$ & \multicolumn{12}{|c|}{3500} \\
\hline $\begin{array}{l}\% \text { of the total } \\
\text { amount of non- } \\
\text { conforming } \\
\text { waste water }\end{array}$ & 2.857 & 5.71 & 8.57 & 2.85 & 14.2 & 5.71 & 11.4 & 8.57 & 11.4 & 8.57 & 5.71 & 14.28 \\
\hline $\begin{array}{l}\text { Legal maximum } \\
\text { load for } \\
\text { laboratory } \\
\text { indicator, } L_{\text {law }}\end{array}$ & 1000 & 2000 & 3000 & 1000 & 5000 & 2000 & 4000 & 3000 & 4000 & 3000 & 2000 & 5000 \\
\hline $\begin{array}{l}\text { The actual load } \\
\text { of the laboratory } \\
\text { index } \mathrm{L}\end{array}$ & 2200 & 4000 & 6000 & 1900 & 9000 & 3400 & 6400 & 4500 & 5600 & 3900 & 2400 & 5500 \\
\hline $\begin{array}{l}\text { Environmental } \\
\text { difference - S }\end{array}$ & 1100 & 2000 & 3000 & 900 & 4000 & 1400 & 2400 & 1500 & 1600 & 900 & 400 & 500 \\
\hline $\begin{array}{l}\text { Total overload } \\
\text { (total } \\
\text { environmental } \\
\text { difference) Ss }\end{array}$ & \multicolumn{12}{|c|}{19700} \\
\hline $\begin{array}{l}\text { Relative } \\
\text { environmental } \\
\text { liability of } \\
\text { indicator }\end{array}$ & 5.583 & 10.15 & 15.22 & 4.568 & 20.3 & 7.1 & 12.18 & 7.61 & 8.12 & 4.568 & 2.03 & 2.538 \\
\hline
\end{tabular}

Source: prepared by the authors. 
It is possible to change the legal limits if one of the enterprises is located on a waterway that has special and different treatment and by following the same method from the previous table to determine responsibility for this proposed laboratory indicator, we find that the total overload (environmental difference) for all the violating enterprises concerning this indicator is an estimate of the amount of $19,700 \mathrm{mg} / \mathrm{m3}$ per year. The total amount of nonconforming industrial wastewater can be determined by adding the annual wastewater amount to all industries, which is $3500 \mathrm{~m} 3 /$ year. In the same way, the relative environmental responsibility of many indicators can be determined based on knowing the legal limits, the amount of annual wastewater, and the actual concentration. The final view of the table will be as follows

Table 7. Proposed Scenarios for a Sample of Industries (A, B, C...) to Determine the State of Compliance with or Breaching the Legal Limits

\begin{tabular}{|c|c|c|c|c|c|c|c|}
\hline Industries & OILY & $\mathrm{NH} 4$ & PHENOL & TSS & BOD & COD & $\begin{array}{l}\text { Amount } \\
\text { of water }\end{array}$ \\
\hline$A$ & 7 & 12 & 6 & 16 & 11 & 10 & 7 \\
\hline B & 14 & 15 & 12 & 11 & 9 & 15 & 16 \\
\hline $\mathrm{C}$ & 27 & 7 & 18 & 15 & 19 & 17 & 18 \\
\hline $\mathrm{D}$ & 6 & 13 & 24 & 13 & 25 & 20 & 9 \\
\hline$E$ & 12 & 24 & 15 & 9 & 20 & 8 & 22 \\
\hline $\mathrm{F}$ & 18 & 15 & 12 & 5 & 6 & 13 & 15 \\
\hline $\mathrm{H}$ & 16 & 14 & 13 & 31 & 10 & 17 & 12 \\
\hline $\begin{array}{l}\text { Total overload weight (total } \\
\text { environmental difference) }\end{array}$ & 7000 & 8000 & 10000 & 12000 & 16000 & 15000 & \\
\hline $\begin{array}{l}\text { Total Amount of wastewater } \\
\text { not-conforming, m3 }\end{array}$ & & & & 3500 & & & \\
\hline
\end{tabular}

Source: prepared by the authors.

By determining the relative environmental responsibility and as shown by the previous table, it is clear that the enterprise $D$, although the amount of water produced by it is small and represents only $9 \%$ of the total amount of non-conforming wastewater, bears responsibility for $20 \%$ of the COD, $25 \%$ of the BOD and $13 \%$ of TSS, NH4 and $24 \%$ of PHENOL and $12 \%$ of OILY; thus, it is the most important establishment on the agenda of environmental decision priorities and needs more inspection, review and environmental monitoring as well as an environmental investment. Through this schedule, a future scenario and more than one scenario can be established if one or some of these facilities are committed at the same time, as follows:

The first scenario: firm B commitment during a specific period: this means eliminating $15 \%$ COD overload, 9\% BOD overload, 11\% TSS overload, 12\% PHENOL overload from an overload of $\mathrm{NH} 4$ at $15 \%$, getting rid of an overload of OILY at $14 \%$ and turning $16 \%$ of the amount of mismatched water into a match. 
The second scenario: firm commitment $C$ during the same specified period: This means eliminating COD overload by $17 \%$, eliminating BOD overload by $19 \%$, eliminating TSS overload by $15 \%$ and eliminating overload from PHENOL by $18 \%$ and eliminating $7 \%$ of $\mathrm{NH} 4$ overload, $27 \%$ of OILY overload, and $18 \%$ of non-conforming water converted into conformity.

The results of the first and second scenarios are the commitment of establishments $B$ and $C$ during the same period, and this determines the extent of environmental improvement in this region by eliminating the COD overload by $32 \%$ and eliminating the overload from BOD by $28 \%$ and eliminating the overload of TSS by $26 \%$, get rid of overload of PHENOL by $30 \%$, get rid of overload of $\mathrm{NH} 4$ by $19 \%$, get rid of overload of OILY by $41 \%$ and convert $34 \%$ of the amount of non-matching water into matching. By applying the above, a specific percentage of the establishment can be inferred by testing the previous example.

Table 8. Pollutant Value and Weight Average

\begin{tabular}{lccccccc}
\hline Indicator & COD & BOD & TSS & Phenol & NH4 & OILY & Total \\
\hline Value & 4 & 4 & 2 & 2 & 3 & 2 & 17 \\
\hline Weighted average & 0.23529 & 0.23529 & 0.11764 & 0.11764 & 0.1764 & 0.11764 & 1 \\
\hline
\end{tabular}

Source: prepared by the authors.

Table 9. The Relative Environmental Liability Calculated with the Percentage of Overloads

\begin{tabular}{cccccccc}
\hline & OILY $\%$ & NH4 $\%$ & PHENOL $\%$ & TSS $\%$ & BOD $\%$ & COD $\%$ & Total \\
\hline A & 7 & 12 & 6 & 16 & 11 & 10 & \\
\hline WIU & 0.11764 & 0.1764 & 0.11764 & 0.11764 & 0.23529 & 0.23529 & \\
\hline & 0.82348 & 2.1168 & 0.70584 & 1.88224 & 2.58819 & 2.3529 & 10.4695 \\
\hline B & 14 & 15 & 12 & 11 & 9 & 15 & \\
\hline & 0.11764 & 0.1764 & 0.11764 & 0.11764 & 0.23529 & 0.23529 & \\
\hline & 1.64696 & 2.646 & 1.41168 & 1.29404 & 2.11761 & 3.52935 & 12.6456 \\
\hline $\mathrm{C}$ & 27 & 7 & 18 & 15 & 19 & 17 & \\
\hline & 0.11764 & 0.1764 & 0.11764 & 0.11764 & 0.23529 & 0.23529 & \\
\hline & 3.17628 & 1.2348 & 2.11752 & 1.7646 & 4.47051 & 3.99993 & 16.7636 \\
\hline $\mathrm{D}$ & 6 & 13 & 24 & 13 & 25 & 20 & \\
\hline & 0.11764 & 0.1764 & 0.11764 & 0.11764 & 0.23529 & 0.23529 & \\
\hline $\mathrm{E}$ & 0.70584 & 2.2932 & 2.82336 & 1.52932 & 5.88225 & 4.7058 & 17.9398 \\
\hline & 12 & 24 & 15 & 9 & 20 & 8 & \\
\hline & 0.11764 & 0.1764 & 0.11764 & 0.11764 & 0.23529 & 0.23529 & \\
\hline $\mathrm{F}$ & 1.41168 & 4.2336 & 1.7646 & 1.05876 & 4.7058 & 1.88232 & 15.0568 \\
\hline & 18 & 15 & 12 & 5 & 6 & 13 & \\
\hline & 0.11764 & 0.1764 & 0.11764 & 0.11764 & 0.23529 & 0.23529 & \\
\hline $\mathrm{H}$ & 2.11752 & 2.646 & 1.41168 & 0.5882 & 1.41174 & 3.05877 & 11.2339 \\
\hline & 16 & 14 & 13 & 31 & 10 & 17 & \\
\hline & 0.11764 & 0.1764 & 0.11764 & 0.11764 & 0.23529 & 0.23529 & \\
\hline & 1.88224 & 2.4696 & 1.52932 & 3.64684 & 2.3529 & 3.99993 & 15.8808 \\
\hline & & & & & & & 99.99 \\
\hline
\end{tabular}

Source: prepared by the authors. 
Table 10. Weight Average of Environmental Responsibility

\begin{tabular}{|c|c|c|c|c|c|c|c|c|}
\hline Industry & $A$ & B & C & D & $E$ & $\mathrm{~F}$ & $\mathrm{H}$ & \\
\hline $\begin{array}{l}\text { Weight } \\
\text { average of the } \\
\text { environmental } \\
\text { responsibility }\end{array}$ & 10.4694 & 12.6456 & 16.7636 & 17.9397 & 15.0567 & 11.233 & 15.8808 & 99.99 \\
\hline
\end{tabular}

\section{Results and Discussion}

The wastewater from industrial activities contains various pollutant loads (residues), which have a significant potential for the industrial pollution. Such pollution may inflict serious damage to human health \& ecosystems, cause direct costs for households and businesses, and hence it posses a serious environmental concern. However water consumption has found to be increased by $185 \%$ and wastewater $\mathrm{m} 3 / \mathrm{kg}$-production by $200 \%$, the use of other materials were found to increase rather than decrease (Abdel-Fatah et al., 2019). Thus we applied the previously mentioned methodology in Abu Quir city which includes many enterprises (both breaching and conforming to the law). According to the Egyptian legislation (the law on protection from pollution no. 48 of 1982), the list of regulated pollutants has been stretched and there were allowed industrial waste discharges into the Nile, its tributaries, lakes, and groundwater, provided that certain quality limits are observed. The following Table 11 shows the listed pollutants with their limits and weighted average.

Table 11. Pollutant Value and Weight from the Total

\begin{tabular}{lcccccc}
\hline Indicator & COD & BOD & TSS & Phenol & OILY & Total \\
\hline Value & 4 & 4 & 2 & 2 & 2 & 14 \\
\hline $\begin{array}{l}\text { Weighted } \\
\text { average }\end{array}$ & 0.2857 & 0.2857 & 0.14825 & 0.14825 & 0.14825 & 1 \\
\hline Legal limit $\mathrm{mg} / \mathrm{L}$ & 100 & 60 & 60 & 0.05 & 10 & 14 \\
\hline
\end{tabular}

Source: prepared by the authors according to the Egyptian legislation (the law on protection from pollution no. 48 of 1982).

Table 12 shows that fertilizer and paper production tops the polluting industries. Phenol represents the highest percentage in paper production, followed by OILY pollutant scoring $55.22 \%$ in the fertilizer production, COD with $44.3 \%$ in paper production, BOD recorded $30.3 \%$ in paper production and TSS recorded $20.1 \%$ in fertilizer industry.

Determining the environmental responsibility according to the extra load for a sample of industries on a list of pollutants according to their weight and relative environment responsibility is shown in the following Table 13. 
Table 12. The Percentage of the Increase in the Industrial Facilities' Relative Loads in Abu Qir

\begin{tabular}{|c|c|c|c|c|c|c|c|c|}
\hline 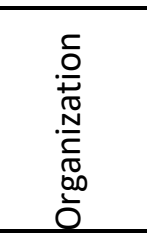 & 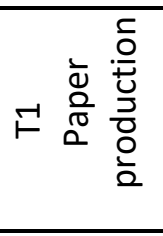 & 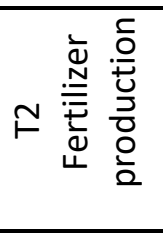 & $m \stackrel{\stackrel{\infty}{\frac{c}{\omega}}}{\stackrel{a}{a}}$ & 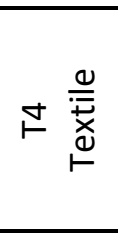 & 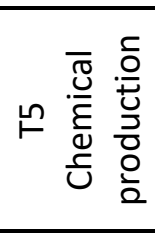 & 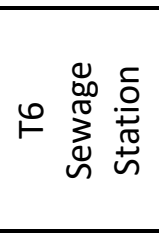 & 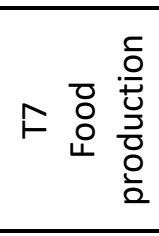 & $\underset{⺊}{\stackrel{5}{E}}$ \\
\hline COD & 44.28 & 43.151 & 5.62 & 4.1 & 2.43 & 0.336 & 0.133 & 100 \\
\hline TSS & 74 & 20.1 & 3.4 & 1.5 & 0.71 & & & 100 \\
\hline OILY & 19.85 & 55.22 & 8.21 & 10.95 & 5.75 & & & 100 \\
\hline BOD & 30.286 & 26.82 & 18.65 & 15.2 & 4.9 & 3.3 & 0.81 & 100 \\
\hline PHENOL & 70.5 & 29.5 & & & & & & 100 \\
\hline
\end{tabular}

Source: The Egyptian ministry of environment, an unpublished report, 2019.

Table 13. Calculation of Relative Environmental Responsibility According to the Extra Load

\begin{tabular}{|c|c|c|c|c|c|c|}
\hline Organization & COD & TSS & OILY & BOD & PHENOL & TOTAL \\
\hline Mamora for paper & 44.28 & 74 & 19.85 & 30.286 & 70.5 & \\
\hline WIU & 0.285 & 0.148 & 0.1483 & 0.2857 & 0.1483 & \\
\hline RWIU & 12.65 & 10.971 & 2.94276 & 8.653 & 10.452 & 44.96 \\
\hline Ahleia for paper & 43.151 & 20.1 & 55.22 & 26.82 & 29.5 & \\
\hline WIU & 0.2857 & 0.1483 & 0.1483 & 0.2857 & 0.1483 & \\
\hline RWIU & 12.328 & 2.979 & 8.186 & 7.6625 & 4.3733 & 34.98 \\
\hline Racta for paper & 5.62 & 3.4 & 8.21 & 18.65 & & \\
\hline WIU & 0.2857 & 0.1483 & 0.1483 & 0.2857 & & \\
\hline RWIU & 1.6056 & 0.5041 & 1.2171 & 5.3283 & & 8.521 \\
\hline $\begin{array}{l}\text { Misr Spinning \& } \\
\text { Weaving - Textile } \\
\text { Unit } \\
\end{array}$ & 4.1 & 1.5 & 10.95 & 15.2 & & \\
\hline WIU & 0.2857 & 0.1483 & 0.1483 & 0.2857 & & \\
\hline RWIU & 1.1714 & 0.2224 & 1.6233 & 4.3426 & & 7.246 \\
\hline $\begin{array}{l}\text { Misr Spinning \& } \\
\text { Weaving - Sabbaghi } \\
\text { El-Beida Unit }\end{array}$ & 2.43 & 0.71 & 5.75 & 4.9 & & \\
\hline WIU & 0.2857 & 0.1483 & 0.1483 & 0.2857 & & \\
\hline RWIU & 0.6943 & 0.1053 & 0.8524 & 1.3999 & & 3.005 \\
\hline $\begin{array}{l}\text { Al-Maamoura } \\
\text { Sewage Station }\end{array}$ & 0.336 & & & 3.3 & & \\
\hline WIU & 0.2857 & & & 0.2857 & & \\
\hline RWIU & 0.096 & & & 0.9428 & & 1.023 \\
\hline Qaha Food & 0.133 & & & 0.81 & & \\
\hline WIU & 0.2857 & & & 0.2857 & & \\
\hline RWIU & 0.038 & & & 0.2314 & & 0.265 \\
\hline TOTAL & & & & & & 100.00 \\
\hline
\end{tabular}

Source: prepared by the authors. 
In the same model, the relative environmental responsibility of several different enterprises in the industrial sector can be determined in a specific geographical area, as well as the relative environmental responsibility of several establishments in the same industrial sector and different geographical places. Table 14 shows that Mamaora's paper is the highest environmental responsibility for damages as it accounted for around $45 \%$ followed by the Ahelia for paper with 34.9\% during 2019, while Qaha food, Al Mamora Sewage, Misr Spinning unit bear the least environmental responsibility for damages.

Table 14. Relative Environmental Responsibility

\begin{tabular}{lcc}
\hline Organization & $\begin{array}{c}\text { Environmental } \\
\text { responsibility }\end{array}$ & TOTAL \\
\hline Mamora for paper & 44.9609 & 45.6684 \\
\hline Ahleia for paper & 34.9798 & 35.5303 \\
\hline Racta for paper & 8.52104 & 8.65512 \\
\hline Misr Spinning \& Weaving - Textile Unit & 7.2457 & 7.35972 \\
\hline Misr Spinning and Weaving - Sabbaghi El-Beida Unit & 3.0046 & 3.05188 \\
\hline Al-Maamoura Sewage Station & 1.02271 & 1.03881 \\
\hline Qaha Food & 0.26524 & 0.26942 \\
\hline TOTAL & 100 & 101.574 \\
\hline
\end{tabular}

Source: prepared by the authors.

Total global water withdrawals in 2025 are projected to increase by 22 percent above 1995 withdrawals, to $4.772 \mathrm{~km}^{3}$, and the projected withdrawals in developing countries will increase 27 percent over the 30-year period,while developed-country withdrawals will increase by 11 percent, (Alcamo et al., 1997; Seckler, 1998). Regions that currently pump groundwater faster than aquifers can recharge, such as the western United States, northern China, northern and western India, Egypt, and West Asia and North Africa, will continue to do so. The cost of supplying water to domestic and industrial users will rise dramatically. Better delivery and more efficient home water use will lead to some increase in the proportion of households connected to piped water. Many households, however, will remain unconnected.Small price increases for industrial water, improvements in pollution control regulation and enforcement, and new industrial technologies will cut industrial water use intensity. Yet industrial water prices will remain relatively low and pollution regulations will often be poorly enforced. Thus, significant potential gains will be lost,( Rosegrant et al., 2002; Rosegrant et al., 2020)

The Egyptian Government has become increasingly aware of the challenges posed by the rapidly growing demands for freshwater, together with Egypt's fixed annual water share of the Nile River. Within this limitation of water resources, and the government aims to bound 
pollution (rather than it become unavoidable), to minimise the sources of industrial pollution emission (Salman, 2011).

Determining the emission inventories are valuable to recognise the magnitude of emissions from various sources, such as traffic, industry, municipal waste burning, power plants, and residential fuel burning. Yet, emission inventories will have difficulties in representing how much each of these sources contributes to ambient loads of a pollutant and do not capture the significance of secondary particulates (sulphates and nitrates) and area-wide sources such as re-suspended dust, windblown dust from the desert, and long distance agricultural burning, This would contribute toward identification of cost-effective interventions for minimization of cost to achieve ambient PM2.5 reduction targets (Larsen, 2019).

The previous measures provide precise assessment to penalize the main industries that participate damaging water which is directly and indirectly affecting population health. Directly, poor WASH causes diarrheal infections and other health effects which is the main reasons to mortality especially in young children (Wolf et al., 2014; Pruss-Ustun et al., 2014; Fewtrell et al., 2007). Indirectly, deprived WASH contributes to poor nutritional status in young (World Bank, 2008; Fewtrell et al., 2007; Larsen, 2007).

\section{Conclusions}

This study aimed to identify the reality of the industrial enterprises' environmental responsibility. The authors answered the research question in terms of tracking the strategy of industrial institutions in environmental management and reached several results concerning paper and fertilizer industries. These industries are on the top of environmental responsibility for damages. A situation that requires developing environmental legislation to meet the modern needs and requirements, as there are many cases of breaching the environmental regulations. Fines should be imposed on those causing the environmental damage and breaching the laws. Then, a Cost Benefit Analysis should take into consideration future damages, rather than current damages. Especially, during the modern era that witnesses acceleration of industrial and technological progress that causes enormous environmental damage.

The paper proposes a strategy which starts by first determining the most damaging load of pollutants according to the new proposed measure; second, by determining the new fines linked with the environmental damage caused by the pollution, third, by providing an incentive for the industry to minimize the environmental damages, which, in turn, may be very profitable for the industry.

To apply the new current pollution control targets in Egypt it is required that the national government should evaluate the fairness of the current allocation scheme of pollutants, reduction targets under the shared responsibility principle by comparing the share in the allocation of environmental responsibility with the pollution reduction target. 
Results require new monitoring of mechanisms for environmental programs and continuous evaluation and development to ensure their compatibility and effectiveness in achieving their goals. Moreover, the government needs to change the criteria for imposing fines on industries that are more responsible for the damages. It is worth mentioning the need for more environmental awareness to be raised for rationalizing the water consumption and building a strong civil society responsibility.

\section{Acknowledgements}

The authors are grateful to Sara El Sers \& Nihal Nashet for reviewing the paper and providing a valuable comment on developing the paper.

\section{References}

Abdel-Fatah, M. A., Hafez, A. I., Gaber, A. H., \& Kamal, M. (2019). Alternative solutions of industrial wastewater management in the textile industry. International Journal of Petrochemical Science \& Engineering, 4(3), 90-95.

Alcamo, J., Döll, P., Kaspar, F., \& Siebert, S. (1997). Global change and global scenarios of water use and availability: an application of WaterGAP 1.0. Kassel, Germany: Center for Environmental Systems Research, University of Kassel.

Estes, R. (1974). A comprehensive corporate social reporting model. The Federal Accountant, 1, 9-20.

Egyptian Law (1982, December 3-4). The Implementer Regulations for Law 48/1982 Regarding the Protection of the River Nile and Waterways from Pollution. Map. Periodical Bull, 12-35.

Fewtrell, L., Prüss-Üstün, A., Bos, R., Gore, F. \& Bartram, J. (2007). Water, Sanitation and Hygiene: Quantifying the Health Impact at National and Local Levels in Countries with Incomplete Water Supply and Sanitation Coverage. Environmental Burden of Disease Series 15. Geneva: World Health Organization.

Larsen, B. (2007). Cost of environmental health risk in children under five years of age: Accounting for malnutrition in Ghana and Pakistan. Background report prepared for the World Bank. Washington, D.C.: Environment Department, The World Bank.

Larsen, B. K. (2019). Egypt: Cost of Environmental Degradation-Air and Water Pollution (No. 142308, pp. 1-0). Washington, D.C.: The World Bank.

Liang, S., Qu, S., Zhu, Z., Guan, D., \& Xu, M. (2017). Income-based greenhouse gas emissions of nations. Environmental Science \& Technology, 51, 346-355. https://doi.org/10. 1021/acs.est.6b02510.

Linowes, D. F. (1972, January). Approach to socio-economic accounting. Conference Board Record, 9(11), 58-61.

Marques, A., Rodrigues, J., Lenzen, M., \& Domingos, T. (2012). Income-based environmental responsibility. Ecological Economics, 84, 57-65. https://doi.org/10.1016/j.ecolecon. 2012.09.010. 
Pruss-Ustun, A., Bartram, J., Clasen, T., Colford, J., et al. 2014. Burden of disease from inadequate water, sanitation, and hygiene in low- and middle-income settings: a retrospective analysis of data from 145 countries. Trop Med Int Health, 19: 894-905.

Pigou, A. C. (2013). The economics of welfare. UK: Palgrave Macmillan.

Qian, Y., Behrens, P., Tukker, A., Rodrigues, J. F., Li, P., \& Scherer, L. (2019). Environmental responsibility for sulfur dioxide emissions and associated biodiversity loss across Chinese provinces. Environmental Pollution, 245, 898-908.

Rosegrant, M. W., Cai, X., \& Cline, S. A. (2002). Global water outlook to 2025: averting an impending crisis. Colombo, Sri Lanka: International Water Management Institute.

Rosegrant, M. W., Cai, X., \& Cline, S. A. (2002). Water and Food to 2025. Colombo, Sri Lanka: International Water Management Institute.

Salman, D. (2011). Industrial development and the trade-off to environment: measurement techniques, meanings and outcomes in the context of water poverty in Egypt. International Journal of Green Economics, 5(1), 87-108.

Seckler, D. W. (1998). World water demand and supply, 1990 to 2025: Scenarios and issues Vol. 19. Colombo, Sri Lanka: Iwmi.

Scoville, J. N. (1995). Value theory and ecology in environmental ethics: a comparison of Rolston and Niebuhr. Environmental Ethics, 17(2), 115-133.

Wolf, J., Pruss-Ustun, A., Cumming, O., Bartram, J., et al. (20140. Assessing the impact of drinking water and sanitation on diarrheal disease in low- and middle-income settings: systematic review and meta-regression. Tropical Medicine and International Health, 19, 928-942.

World Bank. (2008). Environmental health and child survival: Epidemiology, economics, experiences. Washington, D.C.: World Bank. 